\title{
Assessment of the Environmental Significance of Heavy Metals Pollution in Surficial Sediments of South Brittany Waters, France: An Ecological Risk Assessment Approach
}

\section{MENG CHUAN ONG ( $\nabla$ ong@umt.edu.my )}

Universiti Malaysia Terengganu https://orcid.org/0000-0003-0095-6849

Hui-Juan Pan

National Taiwan Ocean University

Noor Azhar Mohamed Shazili

Universiti Malaysia Terengganu

David Menier

Universite de Bretagne-Sud

\section{Virginie Dupont}

Universite de Bretagne-Sud

\section{Sidonie Révillon}

Universite de Bretagne Occidentale

Alexandra Coynel

Universite de Bordeaux

Research article

Keywords: Heavy metals, Bay of Quiberon, Gulf of Morbihan, sediment, sediment quality guidelines

Posted Date: August 6th, 2020

DOI: https://doi.org/10.21203/rs.3.rs-51877/v1

License: (c) (1) This work is licensed under a Creative Commons Attribution 4.0 International License. Read Full License 


\section{Assessment of the Environmental Significance of Heavy}

2 Metals Pollution in Surficial Sediments of South Brittany

3 Waters, France: An Ecological Risk Assessment Approach

4 Ong Meng Chuan ${ }^{1,2,3}$

5 Email: ong@umt.edu.my

6

7 Hui-Juan Pan $^{4,5}$

8 Corresponding author

9 Email: hjpan76@gmail.com

10

11 Noor Azhar Mohamed Shazilii, ${ }^{1,2}$

12 Email: nazhar@umt.edu.my

14 David Menier ${ }^{6}$

15 Email: david.menier@univ-ubs.fr

16

17 Virginie Dupont ${ }^{7}$

18 Email: virginie.dupont@univ-ubs.fr 
20 Sidonie Révillon ${ }^{8,9}$

21 Email: sidonie.revillon@ sedisor.eu

23 Alexandra Coynel $^{10}$

24 Email: alexandra.coynel@u-bordeaux.fr

25

26 (Institutional addresses)

$27{ }^{1}$ Faculty of Science and Marine Environment, Universiti Malaysia Terengganu, 21030 Kuala

28 Nerus, Terengganu, Malaysia

$29{ }^{2}$ Institute of Oceanography and Environment, Universiti Malaysia Terengganu, 21030 Kuala

30 Nerus, Terengganu, Malaysia

313 Ocean Pollution and Ecotoxicology (OPEC) Research Group, Universiti Malaysia

32 Terengganu, 21030 Kuala Nerus, Terengganu, Malaysia

$33{ }^{4}$ Institute of Earth Sciences, College of Ocean Science and Resource, National Taiwan Ocean

34 University, 2 Pei-Ning Road, Keelung, Taiwan 20224, ROC

$35{ }^{5}$ Center of Excellence for Ocean Engineering, College of Engineering, National Taiwan

36 Ocean University, 2 Pei-Ning Road, Keelung, Taiwan 20224, ROC

$37{ }^{6}$ Laboratoire Géosciences Océan (LGO), Université Bretagne Sud, 56017, Vannes, Cedex, 
${ }^{7}$ Département Sciences de la Matière et de la Vie, Université Bretagne Sud, 56017, Vannes,

${ }^{8}$ UMR 6538 Laboratoire Géosciences Océan, Institut Universitaire Européen de la Mer, Place

${ }^{9}$ SEDISOR, Institut Universitaire Européen de la Mer, Place Nicolas Copernic, 29280,

${ }^{10}$ Université de Bordeaux - UMR CNRS 5805 EPOC, Allée Geoffroy Saint Hilaire Bât NB18

\section{Abstract}

Distribution patterns of selected heavy metals content in sediments from the Bay of Quiberon and Gulf of Morbihan were studied to understand the current heavy metals contamination due to urbanization and mariculture activities in the coastal area. Therefore, a survey was conducted and 196 sediments collected were characterized for heavy metals content using

54 Inductively Coupled Plasma - Mass Spectrometry (ICP-MS) after mix acid digestion process.

55 The distribution maps of the concentrations of the heavy metals studied were produced as an 
56 isopleth map based on data interpolation by the ArcGIS software application. The association

57 with the adverse effects on aquatic organisms was determined by the classification of the

58 sediment according to the sediment quality guidelines. Therefore, two approaches were

59 employed namely; direct comparison with Sediment Quality Guidelines (SQGs) by USEPA

60 and comparison with other numerical SQGs, threshold effect level/probable effect level, and

61 effect range low /effect range medium. In order to estimate the effect of multiple

62 contaminations of heavy metals, the mean-ERM-quotient was calculated at each sampling

63 point.

64

65 Keywords

66 Heavy metals, Bay of Quiberon, Gulf of Morbihan, sediment, sediment quality guidelines

67

68 Introduction

69 Nowadays, estuary and coastal environments are contaminated by human activities containing

70 elevated concentrations of heavy metals, nutrients, organic pollutants, and radionuclides

71 (Clark et al. 2000; Kennish 2002). Some chemicals are highly toxic and persistent and have a

72 strong tendency to concentrate in marine food webs. The pollution of coastal zones near

73 metropolitan areas, caused by these anthropogenic wastes is due to the large human 
74 population and the enormous amounts of sewage discharged into coastal waters (Sadiq 2002;

75 Bay et al. 2003). The addition of waste products into rivers and estuaries, particularly those in

76 industrial and population centres has led to a significant increase in contamination of heavy

77 metals (Jayaprakash et al. 2005). Accumulation of heavy metals in surface sediments from

78 industrial effluents and urban discharged into the river without proper cleaning is easily

79 identified by heavy metals spatial variations in sediments (Dauvalter \& Rognerud 2001).

81 Coastal areas are sensitive to both climate changes and human impacts, which make these

82 areas ideal for studying environmental changes and the sequence of coastal sediments, and

83 have become attractive targets for documenting paleoenvironmental changes. The Bay of

84 Quiberon and Gulf of Morbihan are an excellent example of the coastal sea with high

85 terrestrial influence, a semi-enclosed bay, surrounded by densely populated areas and

86 mariculture activities. Such an investigation is required if the environmental impacts of the

87 region are to be understood quantitatively and qualitatively.

89 In this exploration, surficial spatial distributions of selected heavy metals; Copper (Cu), Zinc

$90 \mathrm{(Zn})$, Cadmium $(\mathrm{Cd})$, Lead $(\mathrm{Pb})$ (identified as priority contaminants in aquatic systems by the

91 European Community (EC) Water Framework Directive 2000/60/EC; Tessier et al. 2011) 
92 were characterized in the surficial sediments which reflects the recent input to evaluate the

93 contamination level resulting from anthropogenic inputs. This EC work recommends the

94 monitoring of fluvial loads of heavy metals as a tool for sustainable management in the

95 aquatic ecosystem (Masson et al. 2006).

97 Metals are toxic because they bioaccumulate in which the accumulate in organisms and are

98 higher than in the environment (Gupta 2013; Goretti et al. 2016; Sobihah et al. 2018; Tengku

99 Nur Alia et al. 2020). Furthermore, metals also biomagnify, amplifies through the food chain

100 and accumulates in the top predators (Storelli et al. 2005; Gu et al. 2017; Rodríguez-Jorquera

101 et al. 2017; Bonsignore et al. 2018). Trace metals are also very persistent and difficult to be

102 removed once they enter the body of the organisms (Storelli et al. 2011; Benali et al. 2017; Gu

103 et al. 2018).

104

105 Aim of Research

106 The current study aims to analyze the levels of four heavy metals $(\mathrm{Cu}, \mathrm{Cd}, \mathrm{Pb}$ and $\mathrm{Zn})$ at 196

107 sampling points in the Bay of Quiberon and Gulf of Morbihan surficial sediments. The

108 adverse effects on aquatic organisms were determined by direct comparison with the

109 Sediment Quality Guidelines (SQGs) and the sediment toxicity and ecological risk indices, 
110 namely the effect low range (ERL) / effect range median (ERM), and the threshold effect

111 level (TEL) / probable effect level (PEL) values. In order to estimate the effect of multiple

112 contaminations of heavy metals in the study area, the mean-ERM-quotient was also calculated

113 at each sampling point.

114

115 Methods/Experimental

116 Study Area

117 Bay of Quiberon is a large open-sea area on the south coast of Brittany, consisting of two

118 additional areas with an equivalent surface area of approximately $120 \mathrm{~km}^{2}$ (Figure 1). The bay

119 is roughly triangular, almost completely surrounded by land on the north and east sides; open

120 to the south with the Gulf of Morbihan to the north-east and the narrow peninsula of

121 Quiberon providing protection from the Atlantic Ocean to the west. The Belle, Houat, and

122 Hœdic islands add to the protection of the bay (Proust et al. 2001; Chaumillon et al. 2008).

124 Gulf of Morbihan ("Mor-bihan" = "little sea" in Breton) is a natural harbor located in the

125 South Brittany, northwest France (Figure 1). It is a close sea body (11 500 ha) and a shoreline

126 of $250 \mathrm{~km}$ (Menier et al. 2011). It is a shallow basin with a maximum depth of $30 \mathrm{~m}$ and is

127 connected to the sea by a $900 \mathrm{~m}$ wide and $30 \mathrm{~m}$ deep tidal inlet at Port Novalo (Rossi et al. 
128 2011). Institut Géographique National France recorded that there are 37 islands located in the

129 gulf where the two largest islands are Moine and Arz Islands. The gulf is sheltered from the

130 Atlantic Ocean (Bay of Biscay) by the peninsula of Quiberon, Houat, Hoëdic, and Belle

131 Islands.

132

133 Many areas along the coast are used by the public as recreation areas. A number of shipping

134 ports for recreational purposes and fishing activities are located in this region. In addition, the

135 surrounding coast is successfully used for commercial shellfish (oyster and mussel)

136 mariculture activities with a significant market around the region.

138 Sample Collection

139 This oceanographic fieldwork was carried out by the SEPIOLA research vessel of the

140 University of Rennes1 at the Gulf of Morbihan and vessel of the Regional Committee of

141 Conchyliculture (CRC), South Brittany at the Bay of Quiberon. A total of 196 surficial

142 sediments were collected randomly in Bay of Quiberon and Gulf of Morbihan with Orange

143 Peel Grab sampler. In addition, in order to prevent metals contamination from the wall of the

144 grab, the outermost layer of the sediment samples were removed and only the inner part was

145 kept for further analysis. After collected, the samples were stored in plastic containers and 
146 kept at low temperatures until analysis was carried out.

\section{Laboratory Analysis}

149 Sediment samples were digested and analyses for total heavy metals following published

150 methodologies with some modifications (Ong \& Kamaruzzaman 2009; Kamaruzzaman et al.

151 2008; Kamaruzzaman et al. 2010). The digestion method involved heating of 50mg of a finely

152 powdered sample in a sealed Teflon vessel in a mixture with a mixed acid solution of

153 concentrated $\mathrm{HF}, \mathrm{HNO}_{3}$ and $\mathrm{HCl}$. The Teflon vessel was kept in an oven at $150^{\circ} \mathrm{C}$ for 6 hours.

154 After cooling at room temperature, the solution of the vessel was transferred into a

155 polypropylene test tube. An inductively coupled plasma mass spectrometer, ICP-MS (Perkin

156 Elmer Elan 9000) was used for the quick and precise determination of selected heavy metals

157 in the digested sediment samples. The accuracy was also examined by analyzing duplicate

158 Standard Reference Material 1646a Estuarine Sediment, the results of which were within $\pm 3 \%$

159 of certified values.

160

161 Results and Discussion

162 All the analyzed data were visualized using ArcGIS software and presented in the form of a

163 concentration isopleth map to identify the sediment concentration hotspot as shown in Figure 
164 2. Visualization by overlaying maps using a geographical information system makes this

165 presentation even easier and more successful (Caeiro et al. 2005).

167 Tomlison et al. (1980) elaborated that the application of the pollution load index (PLI)

168 provides a simple way to assess the quality of estuarine and coastal sediment. This assessment

169 is a quick tool for comparing the status of pollution at different locations (Karbassi et al.

170 2006). PLI represents the number of times the concentration of heavy metals in the sediment

171 exceeds the background concentration and provides a summary indication of the overall level

172 of heavy metal toxicity in a particular sample or location (Rabee et al. 2011). The PLI can

173 provide the public in the surrounding area with some understanding of the quality of the

174 components in their environment, indicating the trend both spatially and temporarily

175 (Harikumar \& Jisha, 2010). In addition, it provides valuable information to decision-makers

176 towards better management of pollution levels in the Bay of Quiberon and Gulf of Morbihan

177 regions.

178

179 PLI is obtained as contamination factors (CF). This CF is the quotient obtained by dividing

180 the concentration of each metal with the background value of the metal proposed by

181 Wedepohl (1995). The PLI can be expressed in the following calculation: 
183 where, $\mathrm{n}$ is the number of metals (4 in the present study) and CF is the contamination factor.

184 Background value : Cu $55 \mu \mathrm{g} / \mathrm{g} ; \mathrm{Cd} 0.2 \mu \mathrm{g} / \mathrm{g} ; \mathrm{Pb} 20 \mu \mathrm{g} / \mathrm{g} ; \mathrm{Zn} 70 \mu \mathrm{g} / \mathrm{g}$

185 The CF can be calculated from:

$$
\text { Contamination factor }(C F)=\frac{\text { Element concentration in the sediment }}{\text { Background value of the element }}
$$

186 The background value (of the elements were adopted from Wedepohl (1995) to calculate the

187 CF. The PLI value $>1$ is categorized as polluted, while $<1$ indicates no pollution at the 188 sampling point (Chakravarty \& Patgiri 2009; Seshan et al. 2010).

PLI values of the analyzed surficial sediments were visualized by ArcGIS software and shown in Figure 3, which confirms that either Bay of Quiberon or Gulf of Morbihan is not seriously

192 polluted with the heavy metals studied. PLI was found to be generally low $(<1)$ in all the studied locations in the Bay of Quiberon, apart from Trinité-sur-Mer area. The eastern zone

194 and rivers (Auray, Marle and Noyalo) zones also have a PLI value above 1; therefore these

195 areas can be classified as moderate contamination factors (Seshan et al. 2010).

197 Two approaches were used to assess sediment toxicity and ecological risk to benthic 198 organisms for heavy metals studied in Bay of Quiberon and Gulf of Morbihan surficial 
199 sediments. The first approach was to compare the concentrations of heavy metals to the

200 Sediment Quality Guidelines (SQGs) promulgated by the United States Environmental

201 Protection Agency (USEPA) which were reviewed by Giesy et al. (1990). This approach was

202 used only to screen contaminants of concern in aquatic ecosystems. On the other hand, the

203 second approach was to apply two sets of SQGs developed for marine and estuarine

204 ecosystems (Long \& McDonald 1998) to the assessment the ecotoxicology of the

205 concentration of heavy metals in sediments, namely, (a) the effect range low (ERL)/effect

206 range median (ERM) and (b) the threshold effect level (TEL)/probable effect level (PEL).

208 Based on the SQGs proposed by USEPA from Giesy et al. (1990), sediment contamination is

209 defined as three classes, non-polluted, moderately polluted and heavily polluted (Table 1).

210 This classification of SQGs does consider the natural background or multiple elements (Luo

211 et al. 2010). By comparing the mean concentrations of heavy metals in Bay of Quiberon and

212 Gulf of Morbihan surficial sediments with SQGs, sediments in both areas were classified as

213 non-polluted for $\mathrm{Zn}$, and $\mathrm{Pb}$, and moderately polluted by $\mathrm{Cu}$ and $\mathrm{Cd}$ where these metals

214 exceed SQGs. Surficial sediments from Trinité-sur-Mer zone in Bay of Quiberon, Auray,

215 Marle, Noyalo river zones, and the eastern in Gulf of Morbihan catchment area were

216 moderately enriched with these metals. However, no surficial sediments from both sampling 
217 areas were classified as heavily polluted with the heavy metals studied according to SQGs

218 classification.

219

220 The concentration of heavy metals were evaluated in a screening-level ecological risk

221 assessment by comparing them to another numerical SQGs, namely the threshold effect level

222 (TEL)/probable effect level (PEL), and the effect range low (ERL)/effect range medium

223 (ERM) which were proposed by Long and McDonald (1998). Low range values (i.e., ERL

224 and TEL) are less than expected to have adverse effects on sediment dwelling fauna. In

225 contrast, ERM and PEL represent chemical concentrations above which adverse effects are

226 likely to occur in the aquatic ecosystem (Long \& MacDonald 1998).

228 The SQG values for heavy metals studied in the surficial sediments from the Bay of Quiberon

229 and Gulf of Morbihan and the sediment classification based on these guidelines are shown in

230 Table 2. Results of SQGs classification suggest that all heavy metals in sediments would

231 rarely be expected to cause adverse effects on biota that living in the area.

233 The majority of heavy metals studied did not exceed the corresponding ERL and TEL

234 guideline values and therefore do not pose a risk to marine organisms living in Bay of 
235 Quiberon and Gulf of Morbihan. Only a small percentage of surficial sediments would be

236 classified as possibly posing an occasional threat to the organism due to concentrations of $\mathrm{Cu}$.

237 However, $\mathrm{Cr}, \mathrm{Cu}$, and $\mathrm{Pb}$ in a certain location exceeded the TEL value, particularly from the

238 Gulf of Morbihan surficial sediments. Thus, at a concentration greater than the TEL, the toxic

239 effect of long-term exposure to these heavy metals would be predicted to occur in the station

240 sampled.

241

242 In order to estimate the effect of multiple contaminations on heavy metals, mean-ERM-

243 quotient (M-ERM-Q) was calculated for each surficial sediment in the Bay of Quiberon and

244 Gulf of Morbihan according to Long et al. (1998a), Larrose et al. (2010) and Tessier et al.

245 (2011) as follows:

246

$$
M-E R M-Q=\frac{\sum_{i=1}^{n}\left(C_{i} / E R M_{i}\right)}{n}
$$

248 Where $\mathrm{Ci}$ is the surficial sediment concentrations of element (i), ERMi is the ERM for

249 element (i) and $\mathrm{n}$ is the number of elements, e.g. four heavy metals in this study.

251 Long et al. (1998b) have defined several classes of toxicity probability for biota organisms in

252 their study from US coast based on amphipod survival test: $\mathrm{m}-\mathrm{ERM}-\mathrm{Q}<0.1$ has a $9 \%$ 
probability of toxicity); $0.1<\mathrm{m}-\mathrm{ERM}-\mathrm{Q}<0.5$ has a $21 \%$ probability of being toxic; $0.5<$

$254 \mathrm{~m}-\mathrm{ERM}-\mathrm{Q}<1.5$ has a $49 \%$ of being toxic; and m-ERM-Q $>1.5$ has a $76 \%$ probability of

255 toxicity. Using the concentrations of the heavy metals studied, the m-ERM-Q value was

256 calculated, and the obtained distribution visualized by ArcGIS software in Bay of Quiberon

257 and Gulf of Morbihan is shown in Figure 4.

259 The m-ERM-Q distribution pattern in the Bay of Quiberon surficial sediments showed that

260 the inner bay zone had values below 0.1 , which indicated a $9 \%$ probability of being toxic to

261 the benthic organisms in that area. In the outer bay, the m-ERM-Q values slightly exceed 0.1 ,

262 but not more than 0.2 indicate that this zone is between $9 \%$ and $21 \%$ probability to be toxic to

263 benthic organisms. However, in Trinité-sur-Mer area, m-ERM-Q ranged from 0.2 and 0.3;

264 therefore, this area can be categorized as $21 \%$ probability of toxicity to the benthic organisms

265 according to Long et al. (1998b) classification.

267 Meanwhile, in the gulf of Morbihan sediments, the m-ERM-Q values at the western zone of

268 the gulf were lower than $0.1 \mathrm{~m}$, and therefore this zone can be categorized as $9 \%$ probability of

269 being toxic to the benthic organisms. Towards the inner gulf of eastern zone, the values of $\mathrm{m}-$

270 ERM-Q were increased but do not exceed the $21 \%$ probability of toxicity to the benthic 
271 organisms, 0.2. Generally, some sampling locations located at the rivers zone (Auray, Marle

272 and Noyalo) had the m-ERM-Q value higher than 0.3 , which meant a $21 \%$ probability of

273 toxicity to the benthic organisms. The impact of contaminated sediment probably on aquatic

274 ecosystems is likely to be due to re-suspension and remobilization processes (Tankere-Muller

275 et al. 2007; Kalnejais et al. 2010)

276

277 Abbreviations

278 Cd: Cadmium; CF: contamination factors; CRC: Regional Committee of Conchyliculture; $\mathrm{Cu}$ :

279 Copper; EC: European Community; ERL: effect low range; ERM: effect range median; $\mathrm{HCl}$ :

280 Hydrochloric acid; HF: Hydroflouric acid; $\mathrm{HNO}_{3}$ : Nitric acid; ICP-MS: Inductively Coupled

281 Plasma - Mass Spectrometry, M-ERM-Q: mean-ERM-quotient; Pb: Lead; PEL: probable

282 effect level; PLI: pollution load index; SQGs: Sediment Quality Guidelines; TEL: threshold

283 effect level; USEPA: United States Environmental Protection Agency; Zn: Zinc

284

285 Declarations

286 Availability of data and material

287 Data sharing not applicable to this article as no datasets were generated or analyzed during the

288 current study. Please contact author for data requests. 


\section{Competing interests}

291 The authors declare that they have no competing interest.

292

293 Funding

294 This work was supported by Laboratoire Géosciences Marines et Géomorphologie du Littoral,

295 Université de Bretagne Sud, France and Institute of Oceanography (INOS) under Higher

296 Institution Centre of Excellence (HICoE), Universiti Malaysia Terengganu.

298 Authors' contributions

299 Meng-Chuan Ong proposed the topic, carried out the experimental study, analyzed the data

300 and writing the original draft. Hui-Juan Pan review and editing the manuscript. Noor Azhar

301 Mohamed Shazili, David Menier and Virginie Dupont supervised Meng-Chuan Ong and

302 review and editing the manuscript. Sidonie Révillon and Alexandra Connell help in

303 commenting the manuscript and interpret the results All authors read and approved the final

304 manuscript. 


\section{Acknowledgements}

307 The authors wish to acknowledge their gratitude to the anonymous reviewers who gave freely

308 time and effort, constructive recommendations that enhanced the value of this manuscript.

309 The authors also would like to thank to Mr. Joseph Bidai for his assistance in the detection of

310 heavy metals using ICPMS at Institute of Oceanography and Environment.

312 References

313 Bay SM, Zeng EY, Lorenson TD, Tran K, Alexander C (2003) Temporal and spatial

314 distributions of contaminants in sediments of Santa Monica Bay, California. Mar Environ Res

315 56(1-2): 255-276.

316 Caeiro S, Costa MH, Ramos TB, Fernandes F, Silveira N, Coimbra A, Medeiros G, Painho M

317 (2005) Assessing heavy metal contamination in Sado Estuary sediment: An index analysis

318 approach. Ecol Indic 5(2): 151-169.

319 Chakravarty M, Patgiri AD (2009) Metal pollution assessment in sediments of the Dikrong

320 River, NE India. J Human Ecol 27(1): 63-67.

321 Chaumillon E, Bertin X, Falchetto H, Allard J, Weber N, Walker P, Pouvreau N, Woppelmann

322 G (2008) Multi time-scale evolution of a wide estuary linear sandbank, the Longe de Boyard,

323 on the French Atlantic coast. Mar Geol 251(3-4): 209-223. 
324 Clark MW, Davies-McConchie F, McConchie D, Birch GF (2000) Selective chemical 325 extraction and grain size normalisation for environmental assessment of anoxic sediments:

326 Validation of an integrated procedure. Sci Total Environ 258(3): 149-170.

327 Dauvalter V, Rognerud S (2001) Heavy metal pollution in sediments of the Pasvik River 328 drainage. Chemosphere 42(1): 9-18.

329 Giesy JP, Hoke RA, in R.Baudo, J.P. Giesy and H. Muntau (Eds.), Sediments: Chemistry and 330 Toxicity of In-place Pollutants. Lewis, Chelsea, MI, 1990: 265-348.

331 Harikumar PS, Jisha TS (2010) Distribution pattern of trace metal pollutants in the sediments 332 of an urban wetland in the southwest coast of India. Int J Eng Sci Technol 2(5): 840-850.

333 Jayaprakash M, Srinivasalu S, Jonathan MP, Ram-Mohan V (2005) A baseline study of 334 physico-chemical parameters and trace metals in waters of Ennore Creek, Chennai, India. 335 Mar Pollut Bull 50(5): 583-589.

336 Kalnejais LH, Martin WR, Bothner MH (2010) The release of dissolved nutrients and metals 337 from coastal sediments due to resuspension. Mar Chem 121(1-4): 224-235.

338 Kamaruzzaman BY, Ong MC, Noor Azhar MS, Shahbudin S, Jalal KCA (2008) Geochemistry 339 of sediment in the major estuarine mangrove forest of Terengganu region, Malaysia. Am J $340 \quad$ App Sci 5(12): 1707-1712.

341 Kamaruzzaman BY, Siti Waznah A, Mohd Zahir MS, Ong MC, Shahbudin S, Jalal KCA, Rina 
342 Sharlinda Z, Shuhada AT, Akbar B, Joseph B (2010) Distribution of chromium, manganese

343 and cobalt in the bottom sediment of Pahang River estuary, Pahang, Malaysia. J App Sci

344 10(23), 3122-3126.

345 Karbassi AR, Bayati I, Moatta F (2006) Origin and chemical partitioning of heavy metals in

346 riverbed sediments. Int J Environ Sci Technol 3(1): 35-42.

347 Kennish MJ (2002) Environmental threats and environmental future of estuaries. Environ

348 Conserv 29(1): 78-107.

349 Larrose A, Coynel A, Schäfer J, Blanc G, Massé L, Maneux E (2010) Assessing the current

350 state of the Gironde estuary by mapping priority contaminant distribution and risk potential in

351 surface sediment. J Appl Geochem 25(12): 1912-1923.

352 Long ER, Field LJ, MacDonald DD (1998a) Predicting toxicity in marine sediments with

353 numerical sediment quality guidelines. Environ Toxicol Chem 17(4): 714-727.

354 Long ER, MacDonald DD (1998b) Recommended uses of empirically derived, sediment

355 quality guidelines for marine and estuarine ecosystems. Humam Ecol Risk Assess 4(5): 10193561039.

357 Luo W, Lu YL, Wang TY, Hu WY, Jiao WT, Naile JE, Khim JS, Giesy JP (2010) Ecological 358 risk assessment of arsenic and metals in sediments of coastal areas of northern Bohai and 359 Yellow Seas, China. AMBIO 39(5-6): 367-375. 
Masson M, Blanc G, Schäfer J (2006) Geochemical signals and sources contributions to

361 heavy metal $(\mathrm{Cd}, \mathrm{Zn}, \mathrm{Pb}, \mathrm{Cu})$ fluxes into the Gironde estuary via its major tributaries. Sci

362 Total Environ 370(1): 133-146.

363 Menier D, Tessier B, Dubois A, Goubert E, Sedrati M (2011) Geomorphological and

364 hydrodynamic forcing of sedimentary bedforms - Example of gulf of Morbihan (South

365 Brittahy, Bay of Biscay). J Coast Res 64: 1530-1534.

366 Ong MC, Kamaruzzaman BY (2009) An assessment of metals ( $\mathrm{Pb}$ and $\mathrm{Cu}$ ) contamination in

367 bottom sediment from South China Sea coastal waters, Malaysia. Am J Appl Sci 6(7): 14183681423.

369 Proust JN, Menier D, Guillocheau F, Guennoc P, Bonnet S, Rouby D, Le Corre C (2001) Les

370 vallées fossiles de la baie de la vilaine: nature et évolution du prisme sédimentaire côtier du

371 pleistocène armoricain. Bull Soc Géol Fr 172(6): 737-749.

372 Rabee AM, Al-Fatlawy YF, Najim AA, Nameer M (2011) Using pollution load index (PLI)

373 and geoaccumulation index (I-geo) for the assessment of heavy metals pollution in Tigris

374 river sediment in Baghdad region. Journal of Al-Nahrain University 14(4): 108-114.

375 Sadiq M (2002) Metal contamination in sediments from a desalination plant effluent outfall 376 area. Sci Total Environ 287(1-2): 37-44.

377 Seshan BRR, Natesan U, Deepthi K (2010) Geochemical and statistical approach for 
378 evaluation of heavy metal pollution in core sediments in southeast coast of India. Int $\mathbf{J}$

379 Environ Sci Technol 7(2): 291-306.

380 Tankere-Muller S, Zhang H, Davison W, Finke N, Larsen O, Stahl H, Glud RN (2007) Fine

381 scale remobilization of fe, $\mathrm{Mn}, \mathrm{Co}, \mathrm{Ni}, \mathrm{Cu}$ and $\mathrm{Cd}$ in contaminated marine sediment. Mar

382 Chem 106(1-2): 192-207.

383 Tessier E, Garnier C, Mullot JU, Lenoble V, Arnaud M, Raynaud M, Mounier S (2011) Study

384 of the spatial and historical distribution of sediment inorganic contamination in the Toulon

385 bay (France). Mar Pollut Bull 62(10): 2075-2086.

386 Tomlinson DL, Wilson CR, Harris CR, Jeffrey DW (1980) Problems in the assessment of

387 heavy-metal levels in the estuaries and the formation of a pollution index. Hergoland Mar Res

388 33(1-4): 566-575.

389 Wedepohl KH (1995) The composition of the continental crust. Geochim Cosmochim Acta

390 59(7): 1217-1232.

392 Figure legends

393

394 Figure 1. Map showing surficial sediment sampling points in South Brittany waters

395 Figure 2. Concentration map for heavy metals distribution in South Brittany coastal waters

396 surficial sediment 
397 Figure 3. Contamination category based on PLI values in Bay of Quiberon and Gulf of 398 Morbihan surficial sediments

399 Figure 4. Contamination category based on m-ERM-Q values in Bay of Quiberon and Gulf 400 of Morbihan surficial sediments

401

\section{Table legends}

403 Table 1. Classification of sediment samples $(\mu \mathrm{g} / \mathrm{g})$ based on the proposed SQGs by USEPA

404 Table 2. Classification of sediment samples based on the SQGs 


\section{Figures}

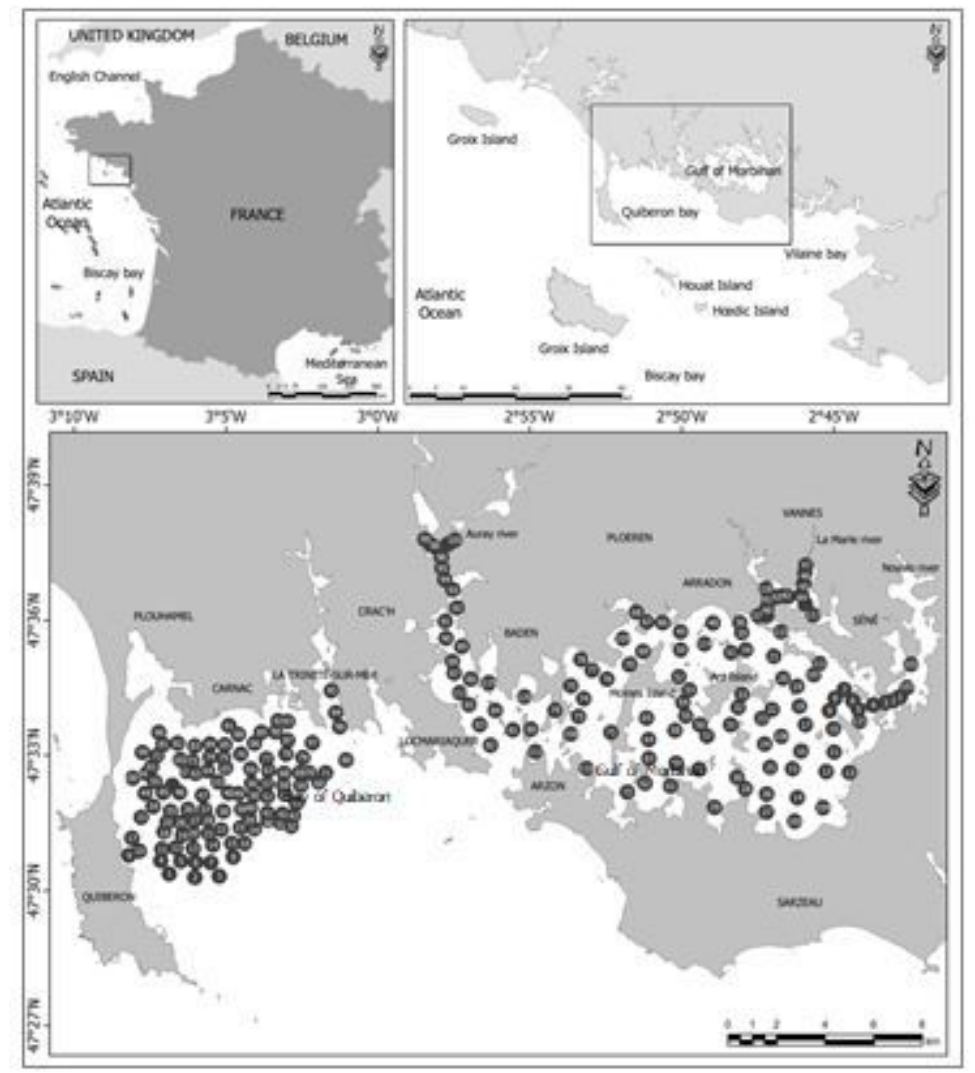

\section{Figure 1}

Map showing surficial sediment sampling points in South Brittany waters

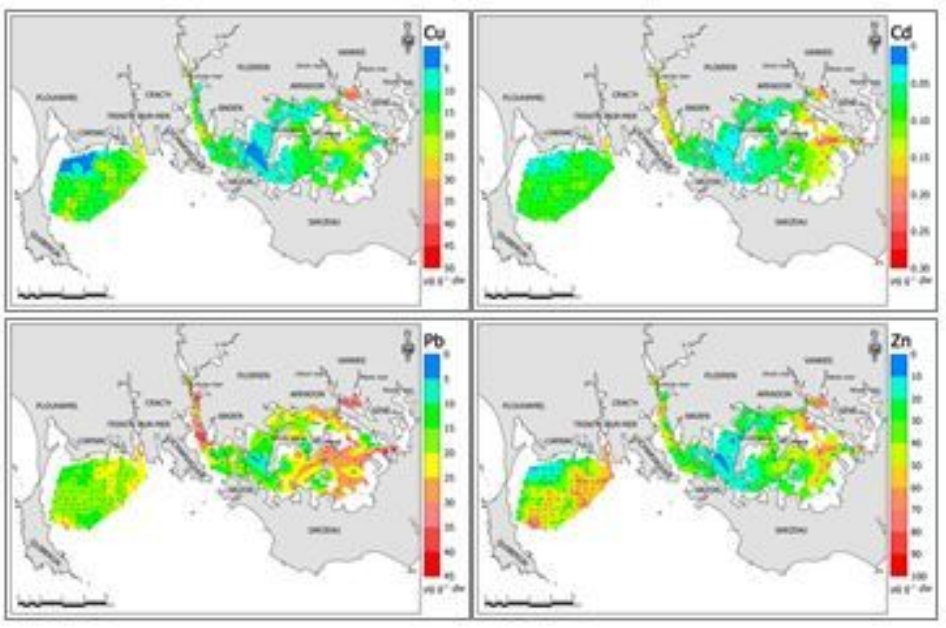

Figure 2

Concentration map for heavy metals distribution in South Brittany coastal waters surficial sediment 


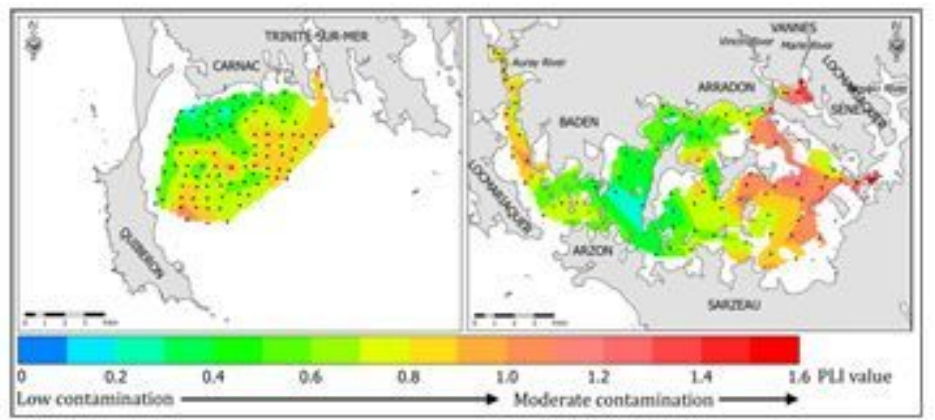

Figure 3

Contamination category based on PLI values in Bay of Quiberon and Gulf of Morbihan surficial sediments

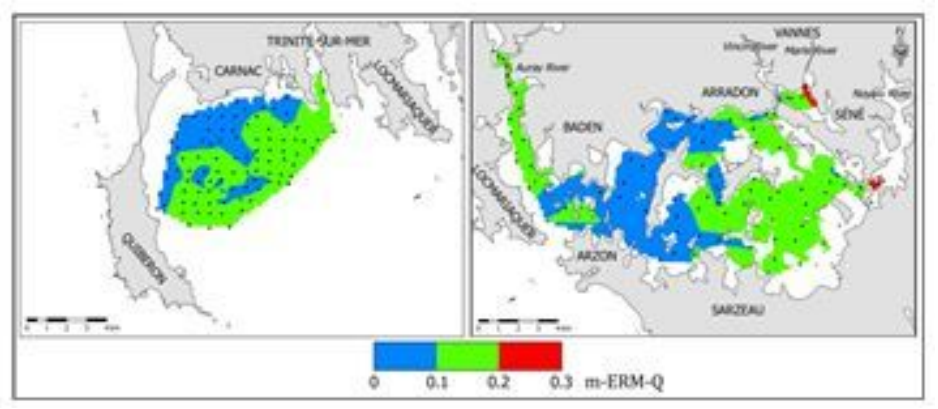

\section{Figure 4}

Contamination category based on $\mathrm{m}-\mathrm{ERM}-\mathrm{Q}$ values in Bay of Quiberon and Gulf of Morbihan surficial sediments

\section{Supplementary Files}

This is a list of supplementary files associated with this preprint. Click to download.

- GraphicAbstract.jpg 